\title{
Breast Cancer pN1 TNM Finding v7
}

National Cancer Institute

\section{Source}

National Cancer Institute. Breast Cancer pN1 TNM Finding v7. NCI Thesaurus. Code C88352.

Breast cancer with micrometastases; or metastases in 1 to 3 axillary lymph nodes;

and/or metastases in internal mammary nodes, with the metastases detected by sentinel lymph node biopsy but not clinically detected. "Not clinically detected" is defined by imaging studies (excluding lymphoscintigraphy) or by clinical examination. (from AJCC 7th Ed.) 